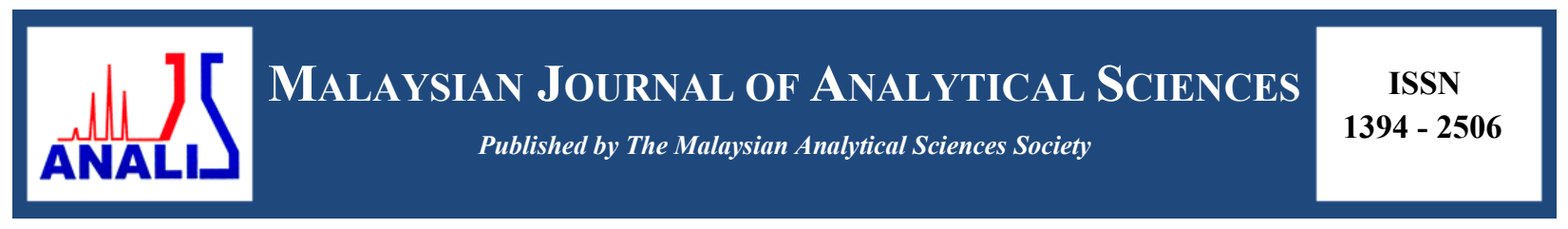

\title{
POLYETHERSULFONE/PLURONIC F127 BLENDED NANOFILTRATION MEMBRANES FOR XYLITOL PURIFICATION
}

\section{(Membran Penurasan-Nano Campuran Polietersulfon/Pluronik F127 untuk Penulinan Xilitol)}

\author{
Khalefa A. Faneer ${ }^{1,2}$, Rosiah Rohani ${ }^{1 *}$, Abdul Wahab Mohammad ${ }^{1}$ \\ ${ }^{I}$ Department of Chemical and Process Engineering, Faculty of Engineering and Built Environment, \\ Universiti Kebangsaan Malaysia, 43600 UKM Bangi, Selangor, Malaysia \\ ${ }^{2}$ Department of Environment Engineering, \\ High Institute for Comprehensive Professions, Bent Baya, Wadi Al-Ajal, Libya.
}

*Corresponding author: rosiah@ukm.edu.my

Received: 21 October 2015; Accepted: 14 June 2016

\begin{abstract}
Obtaining high purity of xylitol is a stone corner in medicine industries. Many conventional techniques (crystallization and adsorption) were used for xylitol purification from fermentation media. Recently, membrane technology received a great attention due to its high performance in xylitol purification. Among renowned copolymers used for polymer blending to produce membranes, pluronic is receiving much attention due to its strong hydrophilic characteristic and could work as pore former and surface modifier. Polyethersulfone (PES) polymer has been reportedly used for polymer blending as it possesses mechanical and chemical stabilities. Therefore, this work demonstrates the preparation of nanofiltration (NF) membrane using: (1) PES and (2) PES blended with $1.71 \%$ and $5 \%$ of Pluronic (F127), via phase inversion method. All fabricated membranes were subjected to investigations such as contact angle for hydrophilicity and water and solution flux for membrane performance. The findings showed increasing in water flux from $24.6 \mathrm{~L} / \mathrm{m}^{2} . \mathrm{h}$ to $70.2 \mathrm{~L} / \mathrm{m}^{2} . \mathrm{h}$ as $5 \%$ of Pluronic added. Further, the hydrophilicity improved from $80.1 \pm 1.93^{\circ}$ to $72 \pm 0.3^{\circ}$ and $67.6 \pm 0.72^{\circ}$ when 1.71 and $5 \%$ of Pluronic F127 added respectively. Therefore, the addition of Pluronic $\mathrm{f} 127$ has a great impact on PES membrane for xylitol permeation.
\end{abstract}

Keywords: polyethersulfone, pluronic F127, xylitol, NF membrane, purification

\section{Abstrak}

Memperoleh ketulenan yang tinggi bagi xilitol merupakan salah satu batu loncatan di dalam industri perubatan. Terdapat banyak teknik konvensional (penghabluran dan penjerapan) yang telah digunakan untuk penulenan xilitol daripada media penapaian. Baru-baru ini, teknologi membran banyak menarik perhatian dengan prestasinya yang bagus dalam penulenan xilitol. Antara kopolimer yang sering digunakan untuk campuran polimer dalam penghasilan membran adalah pluronik yang telah menerima perhatian kerana sifat hidrofiliknya dan boleh membantu dalam pembentukan liang serta pengubahsuai permukaan membran. Polimer polietersulfon (PES) telah dilaporkan digunakan untuk polimer campuran kerana ia mempunyai kestabilan mekanikal dan kimia. Oleh itu, kerja ini menunjukkan penyediaan membran penurasan-nano (NF) menggunakan: (1) PES dan (2) PES dicampur dengan $1.71 \%$ dan 5\% Pluronik (f127), melalui kaedah fasa songsangan. Kesemua membran yang dihasilkan dicirikan menggunakan sudut sentuhan untuk sifat hidrofilik dan fluks air serta larutan bagi prestasi membran. Hasil kajian menunjukkan peningkatan dalam fluks air daripada $24.6 \mathrm{~L} / \mathrm{m}^{2}$.h kepada $70.2 \mathrm{~L} / \mathrm{m}^{2} . \mathrm{h}$ apabila $5 \%$ Pluronik F127 ditambah. Selanjutnya, sifat hidrofilik membran bertambah baik iaitu daripada $80.1 \pm 1.93^{\circ}$ kepada $72 \pm 0.3^{\circ}$ dan $67.6 \pm 0.72^{\circ}$ apabila 1.71 dan $5 \%$ Pluronik F127 ditambah. Didapati penambahan Pluronik F127 memberi kesan yang besar ke atas membran PES untuk penyerapan xilitol.

Kata kunci: polietersulfon, pluronik F127, xylitol, membran NF, penulenan 


\section{Introduction}

Xylitol is classified as a non-cariogenic, beside as a sweetener, it becomes valuable for those who suffer caries and diabetic [1]. This non-cariogenic property makes xylitol an important product in cosmetic, pharmaceutical and food industries [2]. The upstream processing of xylitol production can be achieved by chemical and biotechnological methods [3,4], while the downstream xylitol purification can be accomplished by crystallization, adsorption and membrane technology $[2,5]$. Nanofiltration (NF) membrane has been targeted to be used by many researchers due to its molecular weight cut-off (MWCO) ranges from $200-2000 \mathrm{~g} / \mathrm{mol}$ [6] that will be suitable to purify xylitol $(152.15 \mathrm{~g} / \mathrm{mol})[1,5]$. To fabricate this NF membrane, polyethersulfone (PES) was reportedly used due to its advantages such as easy to synthesize, high chemical resistance and vast $\mathrm{pH}$ tolerance $[7,8]$. Further, PES arise an outstanding oxidative stability [9]. However, the most imperfection of using PES is the lack of hydrophilicity of this polymer, which could leads to fast membrane fouling [10]. This drawback can be minimized by blending hydrophilic copolymer to PES membrane matrix such as polyvinyl pyrrolidone (PVP), polyethylene glycol (PEG) and Pluronic. Among these copolymers, Pluronic F127 was considered as a good pore forming agent and surface modifier because of its chemical stability $[11,12]$.

In recent years, poly (propylene oxide) (PPO) Pluronic triblock copolymers of poly (ethylene oxide) and (PEO) have worked as dual functions as pore former and surface modifier in membrane fabrication [13]. The Pluronic additive (PEO-PPO-PEO) segregated during phase inversion process to the polymer/water interface because of the low interfacial energy between the water and hydrophilic segment, as the water-insoluble, hydrophobic segment of the copolymer promptly anchored in the polymer matrix. [14]. The possible reason is that Pluronic f127 is perfect surfactant, as the surface chemistry of Pluronic F127/PES blend membrane might be reconstructed to reduce the interfacial free energy [15]. PEO chain introduced to the membrane matrix as hydrophilic part where works as adsorption resistant (antifouling) of the molecules as well as hydrophilicity enhancer. i.e. surface modifier. Meanwhile PPO segments represented the hydrophobic units of Pluronic copolymers and distributed closer to the centre of membrane pores $[10,16,17]$. Overall, there are two main processes (presented in Figure 1) lead to formation of PES/ Pluronic F127 via: (1) Aggregation of hydrophilic units which were responsible of surface modifier, and (2) Micellization of hydrophobic units that form the membrane pores.
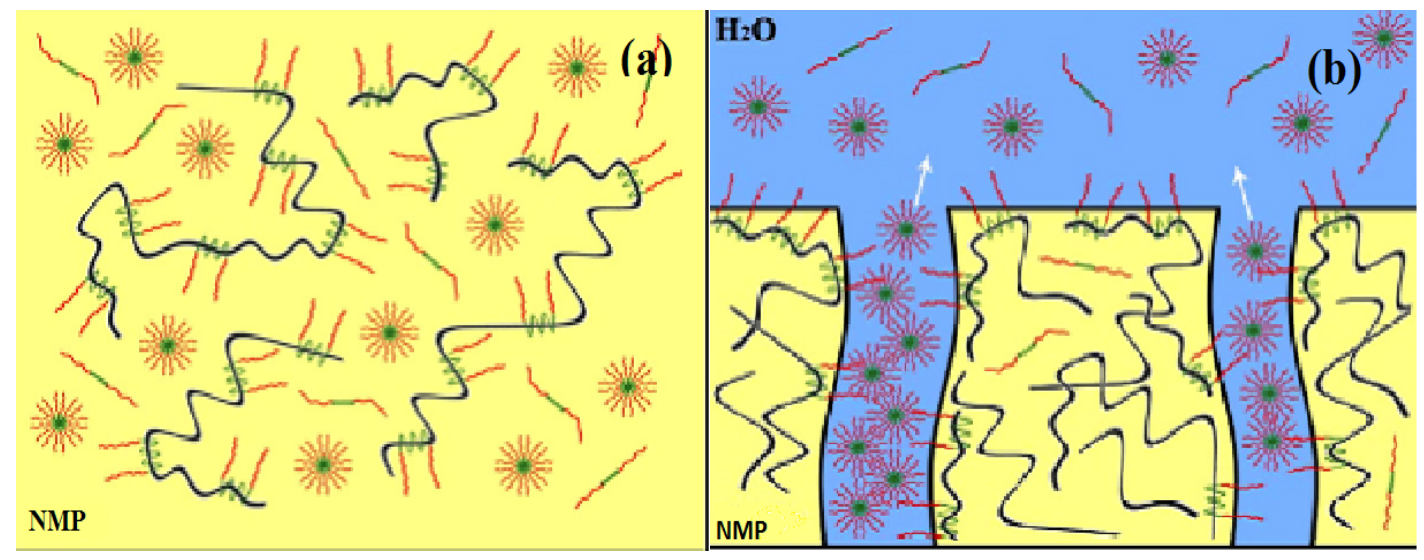

Figure1. Dual function of Pluronic F127 in the membrane formation process via: (a) blending of polymer with Pluronic F127 in a homogeneous dope solution, (b) immersing the membrane in a water bath to form the surface structure and pores in membrane [16].

In most NF membranes synthesis reported, the fabrication via phase inversion process was repeatedly found in the literature due to its simplicity for certain input parameters e.g. using water as the non-solvent [7, 18]. The incorporation of pluronic at a specific ratio to the main polymer was reported $[10,11,15]$ where the main polymer became the backbone of the membrane structure and pluronic acted as the co-polymer. It was also reported on the addition of different additives composition depending on their screening work or optimization conducted, e.g. 
Zhang et al. [15] used 20 to $100 \%$ of pluronic, the $20 \%$ was the best composition for dyes rejection. Chao et al. [13] studied the effect of 1 to $9 \%$ of pluronic on membrane morphology and found that the water flux increased as well as pores and porosity. $\mathrm{Ng}$ et al. [19] found that $1.71 \%$ of polyvinyl alcohol (PVA) is a significant composition to achieve high salt rejection, while Loh et al. [14] investigated systematically the effect of adding 5, 10 and $15 \%$ of pluronic on pore forming of PES membrane and it was found that the best composition is at $10 \%$ as it achieved the highest pure water flux. On the other side, different composition of additives added to the solution could give a significant impact on the mechanical properties of the synthesized membrane as reported by $\mathrm{Ng}$ et al. [19]. Based on the studies, two different composition of Pluronic F127 at 1.71 and 5\% are considered for the fabrication of the membrane using PES and the flux/ rejection of xylitol separation difference is measure.

Thus the aim of this study was to fabricate NF membranes from pure PES and PES blended with Pluronic F127 in 1.71 and $5 \%$ as reported in $[14,19]$ via phase inversion method. Next these membranes were characterized to investigate the pure water flux (PWF), contact angle, separation performance of xylitol mixture solution and the rejection test of xylitol mixture solution.

\section{Materials}

\section{Materials and Methods}

Polyethersulfone (PES) granule, (Good fellow) as the membrane main polymer. Pluronic F127 (Nanoamor) has been used as the copolymer. N-methyl-2-pyrrolidone (NMP) with analytical purity $99.7 \%$ (Fluka, Germany) was used as solvent and distilled water was used as non-solvent. Xylitol, xylose and arabinose powder of 99\% (Acros Organic) were used as received.

\section{Membrane preparation}

The three NF membranes were fabricated via phase inversion under different preparation parameters as tabulated in Table 1. Initially, PES granules were dried at $60{ }^{\circ} \mathrm{C}$ for 72 hours to remove moisture. Each doped solution was stirred for 4 hours to make a homogenous solution. Next, to avoid pinholes and highlights on the membranes, the homogeneous solution was left for 24 hours to release air bubble. Then, the casting machine Elcometer 4340 Automatic Film Applicator with the speed at $76 \mathrm{~mm} / \mathrm{s}$ was used to cast the membranes. A suitable amount of suspension was poured on a glass sheet and cast by casting knife set at $200 \mu \mathrm{m}$ at room temperature. Finally, the fabricated membranes were left for $30 \mathrm{~s}$ for evaporation before submerged in deionized water for 2 hours for solvent exchange purposes. The synthesized membranes were stored in distilled water at ambient temperature prior to use.

Table 1. Polymer doped solution composition and parameters

\begin{tabular}{lcccc}
\hline $\begin{array}{l}\text { PES } \\
\text { (wt. \%) }\end{array}$ & $\begin{array}{c}\text { Pluronic f127 } \\
\text { (wt. \%) }\end{array}$ & $\begin{array}{c}\text { NMP } \\
(\mathbf{w t .} \%)\end{array}$ & $\begin{array}{c}\text { Temperature } \\
\left(\mathbf{C}^{\mathbf{0}} \mathbf{C}\right)\end{array}$ & $\begin{array}{c}\text { Stirring speed } \\
(\mathbf{r p m})\end{array}$ \\
\hline 18 & - & 82 & 60 & 450 \\
18 & 1.71 & 82 & 60 & 450 \\
18 & 5 & 82 & 60 & 450 \\
\hline
\end{tabular}

\section{Membrane characterization: Contact angle}

The contact angle was used to find out the changes in the hydrophilicity to figure out the hydrophilicity of PES and PES/Pluronic F127 membranes. All membranes were dried at room temperature for 48 hours followed by measuring the contact angle using the contact angle goniometer (Rame-Hart model 200) equipped with DROPimage Software with an accuracy of $60.10^{\circ}$. The conditions used to measure the contact angle were under deionized water and air at $\left(25-28^{\circ} \mathrm{C}\right)$. 
Pure water flux (PWF)

Dead-end permeation cell (Sterlitech HP4750, Sterlitech Corporation, USA) was used to evaluate the pure water flux (PWF) of the membranes. The schematic diagram of the dead-end cell is illustrated in Figure 2. The filtration was performed at three different pressures ( 4,6 and 8 bar). The PWF was calculated using equation (1):

$$
J=\frac{\mathrm{V}}{\mathrm{A} * \mathrm{t}}
$$

As $\mathrm{J}$ is PWF $\left(\mathrm{L} / \mathrm{m}^{2} . \mathrm{h}\right)$, A is the effective membrane area $\left(14.6 \mathrm{~cm}^{2}\right), \mathrm{V}$ is the permeate volume $(\mathrm{L})$ and $\mathrm{t}$ is sampling time (h). To minimize experimental errors, 3 to 5 samples were collected and then the average value of Flux was reported.

\section{Permeate flux performance}

The permeate flux performance was conducted using the dead-end cell (Figure 2) at 4 bar with using xylitol mixture solution (xylitol, xylose, and arabinose) and calculated using equation (1). The concentrations of the components in the xylitol mixture are tabulated in Table 2 and the composition is based on the real xylitol fermentation broth as reported by [2].

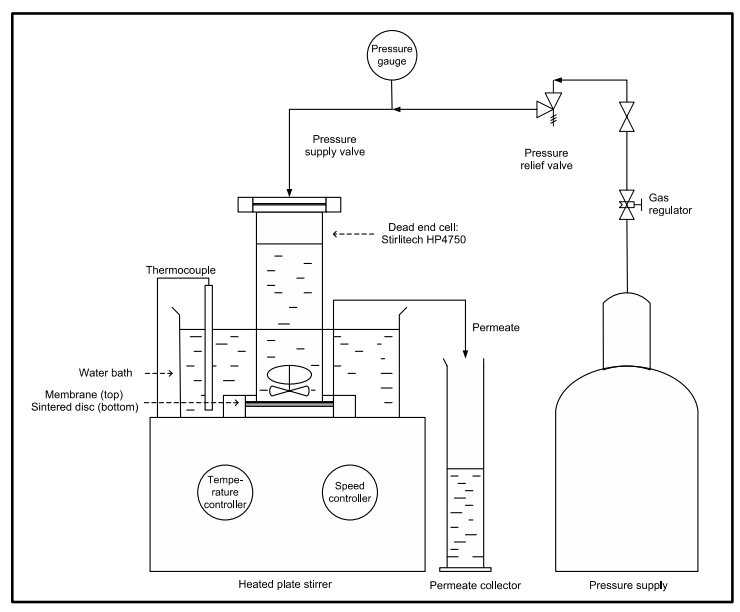

Figure 2. Schematic diagram of the dead end permeation cell [20]

Table 2. Xylitol mixture compositions

\section{Component Concentration (g/L)}

\begin{tabular}{lc}
\hline xylitol & 2 \\
xylose & 0.15 \\
arabinose & 0.3 \\
\hline
\end{tabular}

\section{Rejection test}

The xylitol mixed solution rejection was evaluated on the batch type filtration by using dead-end cell. $300 \mathrm{ml}$ of xylitol mixed solution was poured into this cell. The test was conducted at 4 bars. Equation (2) was used to calculate rejection:

$$
\mathrm{R} \%=\left(1-\frac{C p}{\mathrm{Cf}}\right) * 100
$$


where $\mathrm{R}$ is the rejection, $\mathrm{C}_{\mathrm{p}}$ is the permeate concentration and $\mathrm{C}_{\mathrm{f}}$ is the feed concentration.

The standard calibration curve was plotted to calculate $\mathrm{C}_{\mathrm{p}}$. High performance liquid chromatography (HPLC) (Ultimate 3000, Thermo scientific, USA) coupled with refractive index detector (RID) was used to obtain the solute concentrations under these conditions: Column type: RPM (Rezex, dimension: 300 x $7.8 \mathrm{~mm}$, USA), mobile phase: DI water, detector: Refractive Index (RI) (Refractomax 520, ERC, USA), flow rate: $0.6 \mathrm{~min} / \mathrm{ml}$ and Temperature: $60{ }^{\circ} \mathrm{C}$.

\section{Membrane characterization: contact angle}

\section{Results and Discussion}

As clearly seen in Table 3, the pure PES membrane has the highest contact angle at $80.1 \pm 1.93^{\circ}$. However, when Pluronic F127 at $1.71 \%$ and 5\% were incorporated with the PES membrane, the contact angle has dropped to 72 $\pm 0.3^{\circ}$ and $67.6 \pm 0.72^{\circ}$, respectively. These results indicated that there was an essential surface modification happened at the membrane upon the copolymer incorporation [16, 21]. Lower contact angle represented higher hydrophilicity. Vatanpour et al. [22] explained that when hydrophilic additives were added to the main polymer during the phase inversion process, the hydrophilic additives migrates spontaneously to the membrane/water interface in order to minimize the interface energy and thus resulted in lower contact angle value.

Table 3. Contact angle of all membranes measured at $25^{\circ} \mathrm{C}$

\begin{tabular}{lc}
\hline Membrane Type & Contact Angle $\left.\mathbf{(}^{\circ}\right)$ \\
\hline PES & $80.1 \pm 1.93$ \\
PES/Pluronic 1.71\% & $72 \pm 0.3$ \\
PES/Pluronic 5\% & $67.6 \pm 0.72$ \\
\hline
\end{tabular}

It is also possible that the porous structure on the outer membrane surface is the reason in the contact angle variation, not only influenced by polymer/copolymer interaction during the synthesis [11]. It is believed that by enhancing hydrophilicity of the membrane will result in a better membrane resistance to fouling [23]. Fouling can be occurred due to solution molecules adhesion during the filtration process, which can be considered as a major drawback in membrane application.

\section{Pure water flux}

All pure and Pluronic incorporated PES membranes were initially wetted and further subjected to compaction at 12 bars for 30 min until the PWF have achieved steady state. The PWF of pure and blended PES membranes have varied greatly with the addition of different compositions of the copolymer (Pluronic f127). As shown in Figure 3, the water flux of PES membrane was $24.6 \mathrm{~L} / \mathrm{m}^{2} . \mathrm{h}$ at 4 bars, while for PES/Pluronic F127 at 1.71 and $5 \%$ membranes increased to 63.8 and $70.2 \mathrm{~L} / \mathrm{m}^{2}$.h respectively. This variation might happens due to the change in the hydrophilicity [10] (as discussed in previous section). Vatsha et al. [21] reported that when additive of PVP at 2$10 \%$ was added to neat PES membrane, the water flux increased with regards to the improvement in the membrane hydrophilicity, as well as the enlargement of membrane pores after additive addition.

\section{Permeate flux}

The permeate flux was carried out at 4 bars with the volume capacity of $300 \mathrm{~mL}$ of xylitol mixture solution to evaluate the flux rate profile for PES membranes incorporated with F127 at 1.71 and 5\% in comparison to the pure PES membrane. The concentration of the simulated xylitol mixed solution used in this study exactly followed the work reported by Mussatto [2], which have used real fermentation broth solution to purify xylitol from sugarcane bagasse. Figure 4 showed the improvement of membrane separation after adding $1.71 \%$ and 5\% of pluronic F127. The permeate flux of xylitol mixture was about $27 \mathrm{~L} / \mathrm{m}^{2} . \mathrm{h}$ for pure PES membrane while PES/Pluronic F127 of 1.71 and 5\% membranes could achieved 2-3 times higher fluxes, around 50 and $82 \mathrm{~L} / \mathrm{m}^{2}$.h respectively. Zhao et al. [16] reported that the increase of permeate flux of PES/pluronic membrane compared with pure PES membrane was 
considerably acceptable due to the adjustment/enlargement of PES/Pluronic membrane pore size comparing to PES membrane. These results is also comparable to the work by Susanto et al. [11].

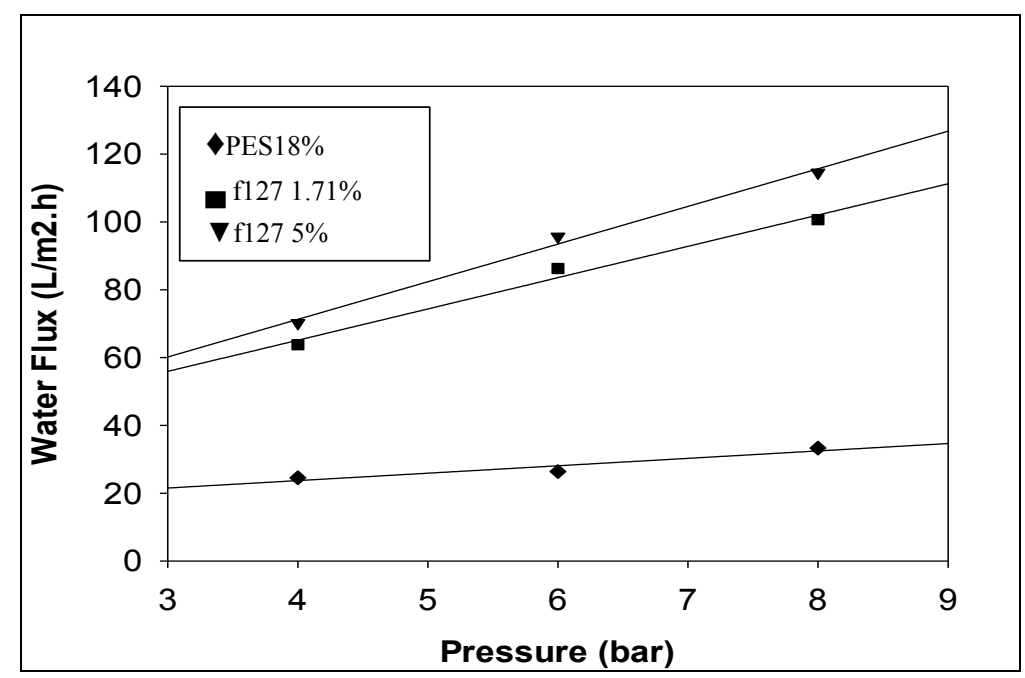

Figure 3. The pure water flux of neat PES and PES/Pluronic F127 (1.71\% and 5\%) at Temperature: $25^{\circ} \mathrm{C}$

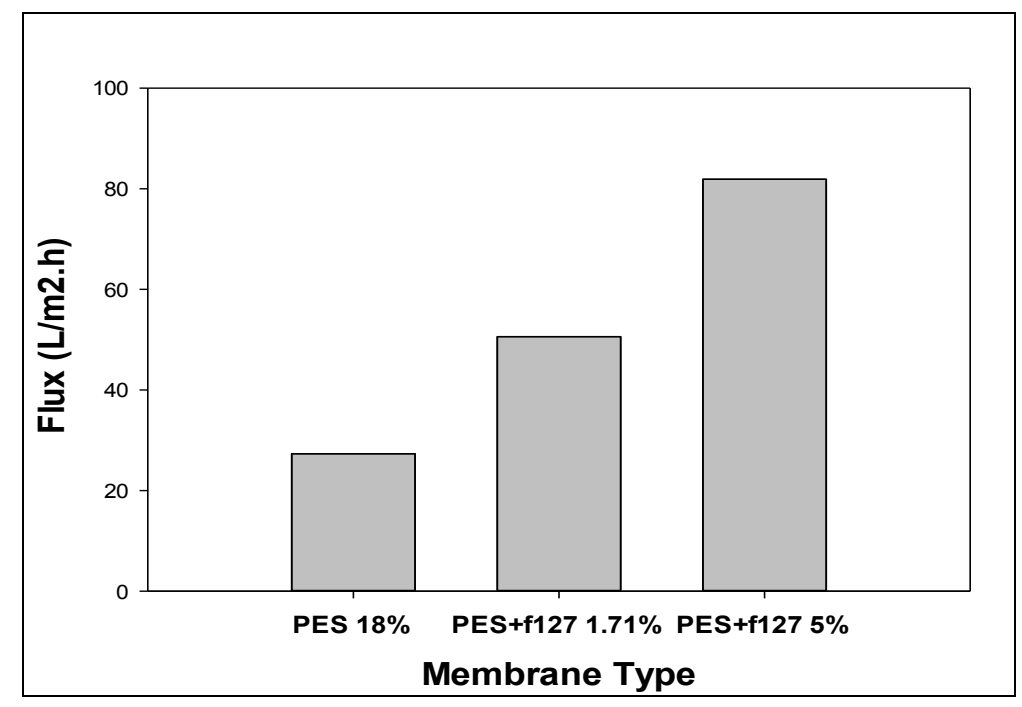

Figure 4. The separation performance of PES and PES/Pluronic membranes. (Stirring speed: $450 \mathrm{rpm}$, Temperature: $25^{\circ} \mathrm{C}$, Pressure: 4 bar).

However, PES/Pluronic membrane at 5\% showed higher normalized fluxes with time compared to pure PES and PES/Pluronic 1.71\% membranes as shown in Figure 5. The flux dropped dramatically at the initial run due to the adsorption and/or deposition of xylitol solution droplets on the membrane surface especially in the first few minutes of operation by the permeate flow. Subsequently, PES/Pluronic $1.71 \%$ membrane achieved slightly higher than neat PES membrane. The permeate fluxes have enhanced because of Pluronic presence, the higher the pluronic composition, the better flux observed for the synthesized membrane. It can be obviously seen that fouling has occurred in PES membrane even at the starting time due to the membrane property, which is less hydrophilic $\left(80^{\circ}\right)$ 
than the PES/pluronic membrane. This result is agreed by Zhao et al. [16] where PES controlled membrane had a remarkably lower flux recovery ratio (FRR) comparing to PES/Pluronic F127 and the FRR value indicates that the higher FRR value for the membrane, the better antifouling and hydrophilicity properties its possess. The xylitol normalized flux was increased in PES/pluronic membranes due to the function of pluronic as pore forming agent. The flux declined over the filtration time is possibly because of the deposition of sugar molecules on the membrane surface to create concentration polarization/ fouling.

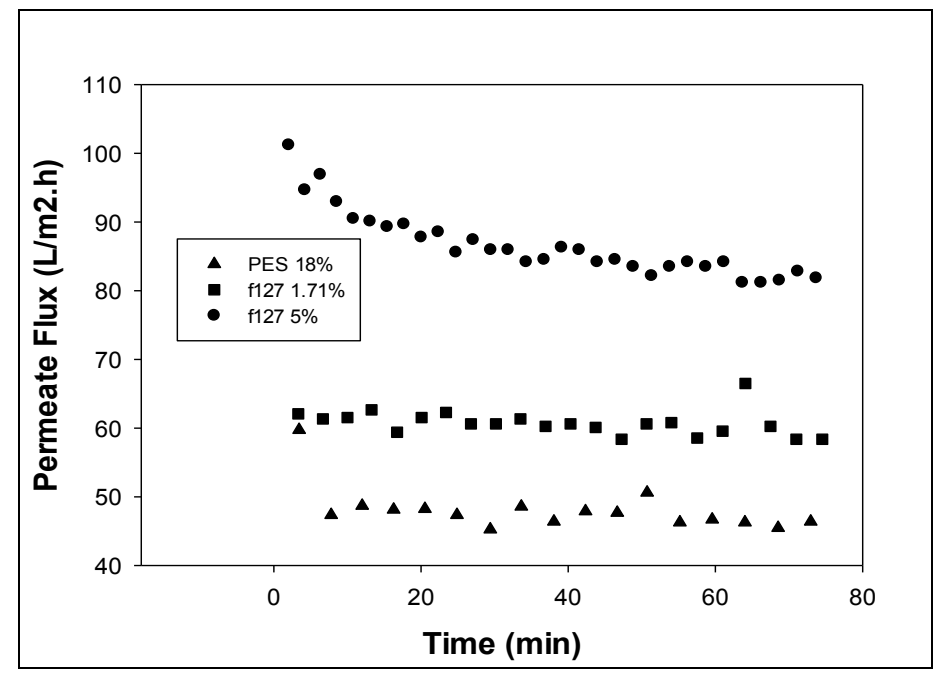

Figure 5. The normalized flux vs time of PES and PES/Pluronic membranes. (Stirring speed: $450 \mathrm{rpm}$, Temperature: $25^{\circ} \mathrm{C}$ )

From the analytical side, addition of pluronic to the dope solution during the synthesis process may have affected on the membrane structure, the hydrophilicity of PES was enhanced; this is because of pluronic hydrophilic character [11]. Thus, the fouling phenomenon was mitigated due to the improvement of hydrophilicity. Zhang et al. [15] observed that when pluronic was added to PES membrane, the hydrophilicity improved positively from $68.4^{\circ} \pm 3^{\circ}$ to $43.3^{\circ} \pm 2^{\circ}$ as pluronic composition increased from 20 to $100 \%$ (polymer weight ratios of $\mathrm{W}_{\mathrm{f} 127} / \mathrm{W}_{\mathrm{PES}}$ are varying in casting solutions ).

\section{Rejection test}

The rejection test was performed to study the capability of PES and PES/Pluronic F127 membranes at 1.71 and 5\% to purify xylitol. It was performed under constant pressure at 4 bars by using xylitol mixture solution. Basically, the calibration curve for three components (xylitol, xylose, and arabinose) was plotted and presented in Figure 6. The calibration curve is required to calculate the permeate concentration, where the equations on the Figure 6 were used for that purposes. Based on the permeate concentration calculated, equation (2) was used to compute the rejection for single PES membrane and for the 1.71 and 5\% PES/ Pluronic F127 membranes. $\mathrm{R}^{2}$ value (linearity) was super high $(\geq 0.96)$ for all plots. This indicates the reliability of the calibration curves to be used to measure the xylitol rejection later.

Table 4 illustrated the rejection results of PES and PES membranes incorporated with 1.71 and 5\% pluronic. It is clearly marked that PES/Pluronic 5\% membrane had the highest rejection $88.1 \%$ compared to $1.71 \% \mathrm{PES} /$ pluronic F127 membrane at $80.6 \%$ and the pure PES membrane rejection was $87.9 \%$. Chao et al. [13] reported that the effects of pluronic composition (1,3,5,7 and $9 \%$ ) on the PES membrane has increased the BSA rejection from about $70 \%$ to around $80 \%$ (about $10 \%$ difference), and doubled the water flux from 210 to $380 \mathrm{~L} / \mathrm{m}^{2}$.h, respectively. Their results are highly corresponded with these findings when 1.71 and $5 \%$ of pluronic F127 were added to PES membrane. Similar results were also reported by Susanto et al. [11] upon conducting the comparison study among 
PVP, PEG and pluronic with PES. They found that the rejection has declined from $87 \%$ (PES membrane) to $72 \%$ (PES/ pluronic 10\% membrane). This shows that with addition of small amount of pluronic F127 to PES membrane, the xylitol rejection rate slightly decreased compared with PES membrane. Whereas, when pluronic composition increases, the rejection slightly increases and relatively better than single PES membrane. It is suggested that PPO units effectively work as pore forming agent due to its hydrophobic character. Moreover, the micellization process is responsible in forming the membrane pores and thus the pore diameter of PES/ Pluronic F127 membrane enlarges. The proposed mechanism is that, during the solvent exchange process, the micelles of Pluronic F127 trap in the skin layer. The interaction between PES and Pluronic F127 micelles lose the skin layer of the shaped membranes. Upon extraction of the hydrophilic Pluronic F127 micelles from the membranes via non-solvent during phase inversion, the regions left in the membranes control the pore size of it. Therefore, the pore radius of the skin layer is strongly affected by the size of Pluronic f127 micelles, which establishes an indirect judgment for pore structure changes, as observed in this work. In addition to that, Kochkodan et al. [24] found that the significant pore enlargement in the membrane surface leads to an increase in the water flux and loss in rejection of bovine serum albumin (BSA).

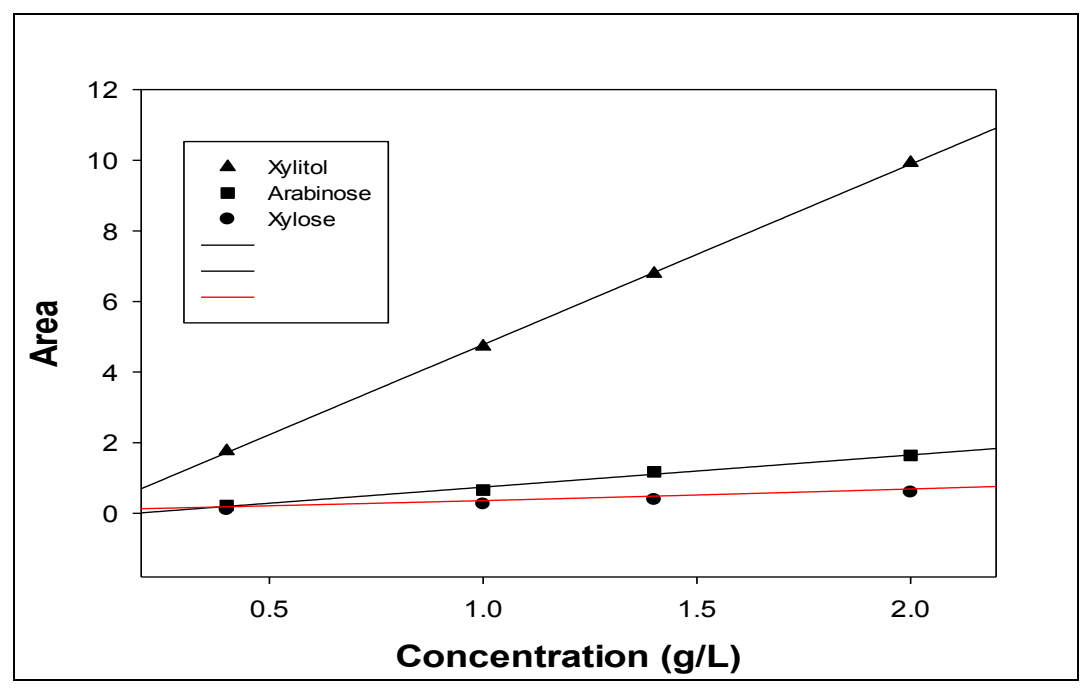

Figure 6. The calibration curve of xylitol, xylose, and arabinose

Table 4. The xylitol, arabinose and xylose rejection of all membranes $\left(\mathrm{T}: 25^{\circ} \mathrm{C}\right.$, Stirring speed : $450 \mathrm{rpm}, \mathrm{P}: 4$ bar)

\begin{tabular}{lccc}
\hline Membrane Type & $\begin{array}{c}\text { Xylitol } \\
\text { Rejection }\end{array}$ & $\begin{array}{c}\text { Arabinose } \\
\text { Rejection }\end{array}$ & $\begin{array}{c}\text { Xylose } \\
\text { Rejection }\end{array}$ \\
\hline PES & 87.9 & 82.7 & 74.7 \\
PES/Pluronic 5\% & 88.1 & 82.3 & 76 \\
PES/Pluronic 1.71\% & 80.6 & 76.3 & 66.7 \\
\hline
\end{tabular}

\section{Conclusion}

The hydrophilic copolymer of Pluronic F127 at two different compositions was successfully incorporated to PES membrane as pore forming agent and surface modifier. This PES blended with Pluronic F127 membranes at 1.71 and 5\% were compared with pure PES membrane. All membranes were fabricated via phase inversion method to purify the desirable xylitol from simulated biomass fermentation broth. The PWF and permeate flux increased to 23 times in presence of Pluronic F127 due to the enlargement of pore diameters and modification of the membrane 
surface by pluronic presence. Whereas, the rejection slightly decreased at the lower amount of pluronic (1.71\%) used which due to PPO role of forming the membrane pores. Characterization for the contact angle of the membranes found that the hydrophilicity improved because of the presence of hydrophilic PEO unite properties in pluronic F127. Both hydrophilic PEO segments and hydrophobic PPO units respectively work as surface modifier and pore former in pluronic.

\section{Acknowledgement}

The authors gratefully acknowledge the LRGS Project Future Biorefineries (LRGS/2013/UKM_UKM/PT/03) and Fundamental Research Grant Scheme (FRGS/2/2013/TK05/UKM/02/4) by Ministry of Science, Technology and Innovation (MOSTI) and Geran Galakan Penyelidikan Muda (GGPM-074-2013) by UKM for providing financial support for this research project.

\section{References}

1. da Silva, S. S. and Chandel, A. K. (2012). d-Xylitol: Fermentative product, application and commercialization. Springer.

2. Mussatto, S. I., Santos, J. C., Ricardo Filho, W. C. and Silva, S. S. (2006). A study on the recovery of xylitol by batch adsorption and crystallization from fermented sugarcane bagasse hydrolysate. Journal of Chemical Technology and Biotechnology, 81(11): $1840-1845$.

3. Rafiqul, I. S. M. and Mimi Sakinah, A. M. (2012). A perspective bioproduction of xylitol by enzyme technology and future prospects. International Food Research Journal, 19(2): 405 - 408.

4. Martinez, E. A., e Silva, J. B. D. A., Giulietti, M. and Solenzal, A. I. N. (2007). Downstream process for xylitol produced from fermented hydrolysate. Enzyme and Microbial Technology, 40(5): 1193 - 1198.

5. Affleck, R. P. (2000). Recovery of xylitol from fermentation of model hemicellulose hydrolysates using membrane technology. Virginia Polytechnic Institute and State University.

6. Bolong, N., Saad, I., Ismail, A. F., Salim, M. R., Rana, D. and Matsuura, T. (2011). Charge property modeling of nanofiltration hollow fiber membranes. International Journal of Simulation: Systems, Science and Technology, 12(3): $12-16$.

7. Li, J. F., Xu, Z. L., Yang, H., Yu, L. Y.and Liu, M. (2009). Effect of $\mathrm{TiO}_{2}$ nanoparticles on the surface morphology and performance of microporous PES membrane. Applied Surface Science, 255(9), 4725 -4732.

8. Zhao, W., Huang, J., Fang, B., Nie, S., Yi, N., Su, B., Li, H. and Zhao, C. (2011). Modification of polyethersulfone membrane by blending semi-interpenetrating network polymeric nanoparticles. Journal of Membrane Science, 369(1): 258 - 266.

9. Su, B., Zhao, C. and Sun, S. (2011). Polyethersulfone hollow fiber membranes for hemodialysis. INTECH Open Access Publisher.

10. Wang, Y. Q., Su, Y. L., Ma, X. L., Sun, Q. and Jiang, Z. Y. (2006). Pluronic polymers and polyethersulfone blend membranes with improved fouling-resistant ability and ultrafiltration performance. Journal of Membrane Science, 283(1): $440-447$.

11. Susanto, H. and Ulbricht, M. (2009). Characteristics, performance and stability of polyethersulfone ultrafiltration membranes prepared by phase separation method using different macromolecular additives. Journal of Membrane Science, 327(1): 125 - 135.

12. Susanto, H., Buchori, L., Sumardiono, S., Fajar, B., Istirokhatun, T. and Widiasa, I. N. (2009). Ultrafiltration as pretreatment of reverse osmosis: Low fouling ultrafiltration membrane prepared from polyethersulfoneamphiphilic block copolymer blend. Reaktor, 12(4): $203-210$.

13. Liu, C., Yun, Y., Wu, N., Hua, Y. and Li, C. (2013). Effects of amphiphilic additive Pluronic F127 on performance of poly (ether sulfone) ultrafiltration membrane. Desalination and Water Treatment, 51(19-21): $3776-3785$.

14. Loh, C. H., Wang, R., Shi, L. and Fane, A. G. (2011). Fabrication of high performance polyethersulfone UF hollow fiber membranes using amphiphilic Pluronic block copolymers as pore-forming additives. Journal of Membrane Science, 380(1): 114 - 123.

15. Zhang, Y., Su, Y., Chen, W., Peng, J., Dong, Y. and Jiang, Z. (2011). A feasible post-treatment of drying and rewetting for preparation of high-flux Pluronic F127/polyethersulfone nanofiltration membranes. Industrial \& Engineering Chemistry Research, 50(8): 4678 - 4685. 
16. Zhao, W., Su, Y., Li, C., Shi, Q., Ning, X. and Jiang, Z. (2008). Fabrication of antifouling polyethersulfone ultrafiltration membranes using Pluronic F127 as both surface modifier and pore-forming agent. Journal of Membrane Science, 318(1): $405-412$.

17. Wang, Y. Q., Su, Y. L., Sun, Q., Ma, X. L. and Jiang, Z. Y. (2006). Generation of anti-biofouling ultrafiltration membrane surface by blending novel branched amphiphilic polymers with polyethersulfone. Journal of Membrane Science, 286(1): 228 - 236.

18. Lalia, B. S., Kochkodan, V., Hashaikeh, R. and Hilal, N. (2013). A review on membrane fabrication: Structure, properties and performance relationship. Desalination, 326: 77 - 95.

19. Ng, L. Y., Leo, C. P. and Mohammad, A. W. (2011). Optimizing the incorporation of silica nanoparticles in polysulfone/poly (vinyl alcohol) membranes with response surface methodology. Journal of Applied Polymer Science, 121(3): $1804-1814$.

20. Rohani, R., Hyland, M. and Patterson, D. (2011). A refined one-filtration method for aqueous based nanofiltration and ultrafiltration membrane molecular weight cut-off determination using polyethylene glycols. Journal of Membrane Science, 382(1): 278 - 290.

21. Vatsha, B., Ngila, J. C. and Moutloali, R. M. (2014). Preparation of antifouling polyvinylpyrrolidone (PVP $40 \mathrm{~K}$ ) modified polyethersulfone (PES) ultrafiltration (UF) membrane for water purification. Physics and Chemistry of the Earth, Parts A/B/C, 67: 125 - 131.

22. Vatanpour, V., Madaeni, S. S., Moradian, R., Zinadini, S. and Astinchap, B. (2011). Fabrication and characterization of novel antifouling nanofiltration membrane prepared from oxidized multiwalled carbon nanotube/polyethersulfone nanocomposite. Journal of Membrane Science, 375(1): 284 - 294.

23. Mulder, J. (2012). Basic principles of membrane technology. Springer Science \& Business Media.

24. Kochkodan, V., Johnson, D. J., and Hilal, N. (2014). Polymeric membranes: Surface modification for minimizing (bio) colloidal fouling. Advances in Colloid and Interface Science, 206: 116 - 140. 